\title{
Structural and Luminescent Properties of $\mathrm{Eu}^{2+}$ and $\mathrm{Nd}^{3+}$-doped Mixed Alkaline Earth Aluminates Prepared by the Sol-gel Method
}

\author{
Nataša Čelan Korošin,* Nataša Bukovec and Peter Bukovec \\ University of Ljubljana, Faculty of Chemistry and Chemical Technology, Department of Inorganic Chemistry \\ Večna pot 113, SI-1000 Ljubljana, Slovenia \\ * Corresponding author: E-mail: natasa.celan@fkkt.uni-lj.si
}

Received: 08-10-2014

Dedicated to the memory of Prof. Dr. Jurij V. Brenčič.

\begin{abstract}
Alkaline earth aluminates with the overall nominal compositions $\mathrm{Mg}_{0.5} \mathrm{Sr}_{0.5} \mathrm{Al}_{2} \mathrm{O}_{4}$ (MSA), $\mathrm{Ca}_{0.5} \mathrm{Mg}_{0.5} \mathrm{Al}_{2} \mathrm{O}_{4}$ (CMA) and $\mathrm{Ca}_{0.5} \mathrm{Sr}_{05} \mathrm{Al}_{2} \mathrm{O}_{4}$ (CSA) doped with $0.5 \mathrm{~mol} \%$ of $\mathrm{Eu}^{2+}$ and $0.25 \mathrm{~mol} \%$ of $\mathrm{Nd}^{3+}$ ions were obtained by a modified aqueous sol-gel method and annealed in a reducing atmosphere at $900,1000,1100$ and $1300{ }^{\circ} \mathrm{C}$. The sample structures were investigated by XRD. Solid solubility was only confirmed for the CSA samples. UV-excited luminescence was observed in the blue region $(\lambda=440 \mathrm{~nm})$ in the samples of CMA containing the monoclinic $\mathrm{CaAl}_{2} \mathrm{O}_{4}$ phase and in the green region $(\lambda=512 \mathrm{~nm})$ in the samples of MSA containing hexagonal or monoclinic phases of $\mathrm{SrAl}_{2} \mathrm{O}_{4}$. The CSA samples, besides the blue region, exhibited an extended shoulder in the green region, which proved the existence of some pure strontium phases. Co-doped $\mathrm{Nd}^{3+}$ ions did not affect the wavelength of the emitted light, but the persistent luminescence at room temperature was greatly extended with respect to the aluminates doped with $\mathrm{Eu}^{2+}$ ions only.
\end{abstract}

Keywords: Sol-gel, Aluminates, Europium, Neodymium, Persistent luminescence, Solid solubility

\section{Introduction}

Alkaline earth aluminates $\mathrm{MAl}_{2} \mathrm{O}_{4}(\mathrm{M}=\mathrm{Ba}, \mathrm{Ca}, \mathrm{Sr})$ doped with the $\mathrm{Eu}^{2+}$ ion and/or co-doped with other rare earth ions $\left(\mathrm{Nd}^{3+}, \mathrm{Dy}^{3+}, \mathrm{Er}^{3+}\right)^{1-6}$ have been studied over the past two decades for their use as persistent luminescent materials. They are most often prepared by solid state reactions, with long reaction times and at high annealing temperatures up to $1600{ }^{\circ} \mathrm{C} .{ }^{2,4-8}$ In addition, some wetchemical techniques have been used to prepare the precursor mixture. Among others, the alkoxy sol-gel route ${ }^{9-12}$ and the aqueous sol-gel route were used ${ }^{13-16}$ with citric or nitric acid as the peptizing agent.

Aluminates with the formulae $\mathrm{M}_{\mathrm{x}} \mathrm{Sr}_{1-\mathrm{x}} \mathrm{Al}_{2} \mathrm{O}_{4}(\mathrm{M}: \mathrm{Ca}$, $\mathrm{Ba} ; \mathrm{x}=0$ to 1$)$ and $\mathrm{Mg}_{\mathrm{x}} \mathrm{Sr}_{1-\mathrm{x}} \mathrm{Al}_{2} \mathrm{O}_{4}(\mathrm{x}=0.05$ to 0.25$)$ doped with $\mathrm{Eu}^{2+}$ and $\mathrm{Nd}^{3+}$ ions were also prepared by conventional solid state reactions with the aim of investigating their structural properties in relation to their luminescent abilities. ${ }^{8,17,18}$ In some cases the $\mathrm{Ca} / \mathrm{Sr}$ or $\mathrm{Mg} / \mathrm{Sr}$ replacement enhanced the persistence of their luminescen- ce. The solid solubility of $\mathrm{Ca}_{1-\mathrm{x}} \mathrm{Sr}_{\mathrm{x}} \mathrm{Al}_{2} \mathrm{O}_{4}$ was expected since the $\mathrm{Sr}^{2+}$ ion is only $11 \%$ larger than the $\mathrm{Ca}^{2+}$ ion, and both parent compounds have similar tridymite-type structures. ${ }^{17,19}$

Persistent luminescence is an optical phenomenon, whereby the material is excited with high-energy radiation (visible light, UV radiation, electron beam, plasma beam, X-rays) and the resulting visible emission remains that way for many hours after the excitation has stopped. ${ }^{6}$

Alkaline earth aluminates doped with $\mathrm{Eu}^{2+}$ exhibit luminescent properties in the blue/green visible range relating to the host lattice. ${ }^{6,20}$ It is also known that co-doping with other rare earth ions $\left(\mathrm{Dy}^{3+}, \mathrm{Nd}^{3+}, \mathrm{Tm}^{3+}\right)$ extends the lifetime of the persistent luminescence and the intensities of these materials due to the existence of long-lived trap levels. ${ }^{6-8,17,18,20-26}$

Recently, we studied alkaline earth aluminates with the overall nominal compositions $\mathrm{Ca}_{0.5} \mathrm{Sr}_{0.5} \mathrm{Al}_{2} \mathrm{O}_{4}$ (CSA), $\mathrm{Mg}_{0.5} \mathrm{Sr}_{0.5} \mathrm{Al}_{2} \mathrm{O}_{4}$ (MSA) and $\mathrm{Ca}_{0.5} \mathrm{Mg}_{0.5} \mathrm{Al}_{2} \mathrm{O}_{4}$ (CMA) doped with 0.5 or $1 \mathrm{~mol} \%$ of $\mathrm{Eu}^{2+}$ ions. ${ }^{15,16}$ The 
materials were prepared by employing the aqueous solgel route, using nitric acid as the peptizing agent, and annealed in a reducing atmosphere at various temperatures from 900 to $1300{ }^{\circ} \mathrm{C}$. Structural studies showed the presence of various phases obtained at different annealing temperatures.

In this work we studied alkaline earth aluminates with the overall nominal compositions $\mathrm{Mg}_{0.5} \mathrm{Sr}_{0.5} \mathrm{Al}_{2} \mathrm{O}_{4}$ (MSA), $\mathrm{Ca}_{0.5} \mathrm{Mg}_{0.5} \mathrm{Al}_{2} \mathrm{O}_{4}$ (CMA) and $\mathrm{Ca}_{0.5} \mathrm{Sr}_{0.5} \mathrm{Al}_{2} \mathrm{O}_{4}$ (CSA) doped with $\mathrm{Eu}^{2+}$ and $\mathrm{Nd}^{3+}$ ions, obtained by a modified aqueous sol-gel method. The influence of the annealing temperature on the structure and, consequently, on the luminescence properties was investigated.

\section{Experimental}

\section{1. Sample Preparation}

All the starting chemicals $\left(\mathrm{Al}\left(\mathrm{NO}_{3}\right)_{3} \cdot 9 \mathrm{H}_{2} \mathrm{O}\right.$, $\mathrm{Ca}\left(\mathrm{NO}_{3}\right)_{2} \cdot 4 \mathrm{H}_{2} \mathrm{O}, \mathrm{Mg}\left(\mathrm{NO}_{3}\right)_{2} \cdot 6 \mathrm{H}_{2} \mathrm{O}, \mathrm{Sr}\left(\mathrm{NO}_{3}\right)_{2}, \mathrm{Eu}_{2} \mathrm{O}_{3}$ and $\mathrm{Nd}_{2} \mathrm{O}_{3}$ ) were analytical grade reagents purchased from Aldrich.

The polycrystalline aluminates MSA, CMA and CSA, doped with $0.5 \mathrm{~mol} \% \mathrm{Eu}^{2+}$ and $0.25 \mathrm{~mol} \%$ of $\mathrm{Nd}^{3+}$ (in mol\% of the total amount of alkaline earth metals), were prepared using the sol-gel method. Gaseous ammonia was introduced into a $0.05 \mathrm{M}$ aqueous solution of $\mathrm{Al}\left(\mathrm{NO}_{3}\right)_{3}$ to precipitate $\mathrm{Al}(\mathrm{OH})_{3}$ at $\mathrm{pH} 9$; this was then filtered and washed with deionised water. A transparent sol was prepared by peptizing the $\mathrm{Al}(\mathrm{OH})_{3}$ with $1 \mathrm{M} \mathrm{HNO}_{3}$, admixing appropriate amounts of solutions of $\mathrm{Ca}^{2+}, \mathrm{Mg}^{2+}$, $\mathrm{Sr}^{2+}, \mathrm{Eu}^{3+}$ and $\mathrm{Nd}^{3+}$ ions and heating at $80{ }^{\circ} \mathrm{C}$ for 4 hours. The xerogel was obtained by heating the sol in a Petri dish at $80{ }^{\circ} \mathrm{C}$. Portions were then annealed in a tubular oven in a reducing atmosphere $\left(\mathrm{Ar} / \mathrm{H}_{2}-5 \%\right)$ at various temperatures $\left(900,1000,1100,1300{ }^{\circ} \mathrm{C}\right)$ for 3 hours. ${ }^{15,16}$ The reducing atmosphere was needed to obtain $\mathrm{Eu}^{2+}$ ions as luminescent centres.

\section{2. Instrumental Methods}

The phases of the calcined materials were identified by Crystallographica Search Match ${ }^{27}$ using the PDF-4 database $^{28}$ from their X-ray powder diffraction patterns, collected using a PANalytical X'Pert PRO diffractometer with $\mathrm{CuK}_{\alpha}$ radiation $(\lambda=1.5406 \AA)$ in the range of $2 \theta=$ $5^{\circ}-80^{\circ}$ in steps of $0.034^{\circ}$ with a total integration time of $100 \mathrm{~s}$ per step (the full range of the 128 channel linear RTMS detector was used, so that each channel integrated the intensity for about $0.78 \mathrm{~s}$ at each step). The total collection time was $28.8 \mathrm{~min}$.

The luminescence spectra were measured at room temperature using a Perkin Elmer LS-5 spectrometer in the range $400-650 \mathrm{~nm}$ using a powder sample holder. A total of $25 \mathrm{mg}$ of the sample was distributed on the sur- face of the holder with a surface area of $1 \mathrm{~cm}^{2}$. The widths of the excitation and emission slits were set to $5 \mathrm{~nm}$ and $8 \mathrm{~nm}$, respectively. The excitation wavelength was $350 \mathrm{~nm}$.

The persistent luminescence spectra were measured with a Mettler Toledo HP DSC $827^{\mathrm{e}}$ analyser equipped with a PCO SensiCam at room temperature after exposure to an $\mathrm{Hg}$ lamp for $5 \mathrm{~min}$. The delay between the initial irradiation and the afterglow measurements was $3 \mathrm{~min}$. A total of $8 \mathrm{mg}$ of the sample was distributed in a $40 \mu \mathrm{L}$ aluminium holder with a surface area of approximately 28 $\mathrm{mm}^{2}$. During measurement the camera shutter was set to $\mathrm{f} / 0.95$ and the exposure time was 3 seconds. The sampling utilized a 12 bit DAC (digital-to-analogue converter); therefore, the sample values ranged between 0 and 4095 in arbitrary units.

\section{Results and Discussion}

The thermal treatment of the xerogels as precursors of the alkaline earth aluminates doped with $\mathrm{Eu}^{2+}$ ions had a strong effect on the structure and, consequently, on the luminescence properties of these materials. A variety of phases of the material with different luminescence properties were obtained, as reported. ${ }^{15,16} \mathrm{Co-doping}$ with $\mathrm{Nd}^{3+}$ ions caused not only an improved persistent luminescence, but also some structural changes in the material. So, the investigation of their structures on a qualitative level was necessary.

\section{1. Phase Compositions}

All the samples of MSA: $0.5 \mathrm{Eu}^{2+}, 0.25 \mathrm{Nd}^{3+}, \mathrm{CMA}$ : $0.5 \mathrm{Eu}^{2+}, 0.25 \mathrm{Nd}^{3+}$ and CSA: $0.5 \mathrm{Eu}^{2+}, 0.25 \mathrm{Nd}^{3+}$, annealed at the temperatures mentioned above, contained up to five of the following phases: cubic $\mathrm{MgAl}_{2} \mathrm{O}_{4}, \mathrm{Sr}_{3} \mathrm{Al}_{2} \mathrm{O}_{6}, \mathrm{CaSr}_{2}$ $\mathrm{Al}_{2} \mathrm{O}_{6}, \mathrm{Ca}_{2} \mathrm{SrAl}_{2} \mathrm{O}_{6}$ and $\mathrm{Ca}_{3} \mathrm{Al}_{2} \mathrm{O}_{6}$; monoclinic $\mathrm{CaAl}_{2} \mathrm{O}_{4}$, $\mathrm{SrAl}_{2} \mathrm{O}_{4}$; and hexagonal $\mathrm{SrAl}_{2} \mathrm{O}_{4}$. The formulae of the phases, listed in the databases, are given for clarity, although it is known that in some systems (especially $\mathrm{Ca}-\mathrm{Sr}$ aluminates) solid solutions are formed. ${ }^{15,19}$

The phase compositions obtained are presented in Table 1. The phases are listed in the order of their appearance.

Fig. 1 shows the crystalline and phase development with the increased temperature of annealing for a typical sample of MSA: $0.5 \mathrm{Eu}^{2+}, 0.25 \mathrm{Nd}^{3+}$. The cubic $\mathrm{MgAl}_{2} \mathrm{O}_{4}$ phase started to crystallize at $900{ }^{\circ} \mathrm{C}$. With an increase of the annealing temperature the diffraction peaks sharpened and the intensities grew, at $1300{ }^{\circ} \mathrm{C}$ the fully crystallized phase was formed (PDF 82-2424). At a subsequent temperature two strontium phases were present. The dominant monoclinic $\mathrm{SrAl}_{2} \mathrm{O}_{4}$ phase (PDF 34-379) developed from the hexagonal $\mathrm{SrAl}_{2} \mathrm{O}_{4}$ phase (PDF 31-1336), which was fully crystalized at lower temperatures $\left(900{ }^{\circ} \mathrm{C}\right)$ and the 
Table 1. Selected results of the Search Match analysis.

\begin{tabular}{|c|c|c|c|c|}
\hline \multirow[b]{2}{*}{ Sample } & \multicolumn{4}{|c|}{ Temperature } \\
\hline & $900{ }^{\circ} \mathrm{C}$ & $1000{ }^{\circ} \mathrm{C}$ & $1100{ }^{\circ} \mathrm{C}$ & $1300{ }^{\circ} \mathrm{C}$ \\
\hline MSA:0.5Eu ${ }^{2+} 0.25 \mathrm{Nd}^{3+}$ & $\begin{array}{l}\mathrm{Sr}_{3} \mathrm{Al}_{2} \mathrm{O}_{6} \text { cubic } \\
\mathrm{SrAl}_{2} \mathrm{O}_{4} \text { hexagonal } \\
\mathrm{MgAl}_{2} \mathrm{O}_{4} \text { cubic }\end{array}$ & $\begin{array}{l}\mathrm{Sr}_{3} \mathrm{Al}_{2} \mathrm{O}_{6} \text { cubic } \\
\mathrm{SrAl}_{2} \mathrm{O}_{4} \text { hexagonal } \\
\mathrm{MgAl}_{2} \mathrm{O}_{4} \text { cubic } \\
\mathrm{SrAl}_{2} \mathrm{O}_{4} \text { hexagonal }\end{array}$ & $\begin{array}{l}\mathrm{Sr}_{3} \mathrm{Al}_{2} \mathrm{O}_{6} \text { cubic } \\
\mathrm{SrAl}_{2} \mathrm{O}_{4} \text { monoclinic } \\
\mathrm{MgAl}_{2} \mathrm{O}_{4} \text { cubic }\end{array}$ & $\begin{array}{l}\mathrm{SrAl}_{2} \mathrm{O}_{4} \text { monoclinic } \\
\mathrm{Sr}_{3} \mathrm{Al}_{2} \mathrm{O}_{6} \text { cubic } \\
\mathrm{MgAl}_{2} \mathrm{O}_{4} \text { cubic }\end{array}$ \\
\hline CMA:0.5Eu ${ }^{2+} 0.25 \mathrm{Nd}^{3+}$ & $\begin{array}{l}\text { Poorly crystalline phase of } \\
\mathrm{MgAl}_{2} \mathrm{O}_{4} \text { could be seen only }\end{array}$ & $\begin{array}{l}\mathrm{MgAl}_{2} \mathrm{O}_{4} \text { cubic } \\
\mathrm{CaAl}_{2} \mathrm{O}_{4} \text { monoclinic }\end{array}$ & $\begin{array}{l}\mathrm{MgAl}_{2} \mathrm{O}_{4} \text { cubic } \\
\mathrm{MgAl}_{2} \mathrm{O}_{4} \text { cubic }\end{array}$ & $\begin{array}{l}\mathrm{CaAl}_{2} \mathrm{O}_{4} \text { monoclinic } \\
\mathrm{CaAl}_{2} \mathrm{O}_{4} \text { monoclinic }\end{array}$ \\
\hline CSA:0.5Eu ${ }^{2+} 0.25 \mathrm{Nd}^{3+}$ & $\begin{array}{l}\mathrm{CaSr}_{2} \mathrm{Al}_{2} \mathrm{O}_{6} \text { cubic } \\
\mathrm{SrAl}_{2} \mathrm{O}_{4} \text { monoclinic } \\
\mathrm{CaAl}_{2} \mathrm{O}_{4} \text { monoclinic } \\
\mathrm{Ca}_{3} \mathrm{Al}_{2} \mathrm{O}_{6} \text { cubic } \\
\mathrm{Sr}_{3} \mathrm{Al}_{2} \mathrm{O}_{6} \text { cubic }\end{array}$ & $\begin{array}{l}\mathrm{CaSr}_{2} \mathrm{Al}_{2} \mathrm{O}_{6} \text { cubic } \\
\mathrm{CaAl}_{2} \mathrm{O}_{4} \text { monoclinic } \\
\mathrm{SrAl}_{2} \mathrm{O}_{4} \text { monoclinic } \\
\mathrm{Ca}_{3} \mathrm{Al}_{2} \mathrm{O}_{6} \text { cubic }\end{array}$ & $\begin{array}{l}\mathrm{Ca}_{2} \mathrm{SrAl}_{2} \mathrm{O}_{6} \text { cubic } \\
\mathrm{SrAl}_{2} \mathrm{O}_{4} \text { monoclinic } \\
\mathrm{CaAl}_{2} \mathrm{O}_{4} \text { monoclinic }\end{array}$ & $\begin{array}{l}\mathrm{Ca}_{2} \mathrm{SrAl}_{2} \mathrm{O}_{6} \text { cubic } \\
\mathrm{CaAl}_{2} \mathrm{O}_{4} \text { monoclinic } \\
\mathrm{SrAl}_{2} \mathrm{O}_{4} \text { monoclinic }\end{array}$ \\
\hline
\end{tabular}

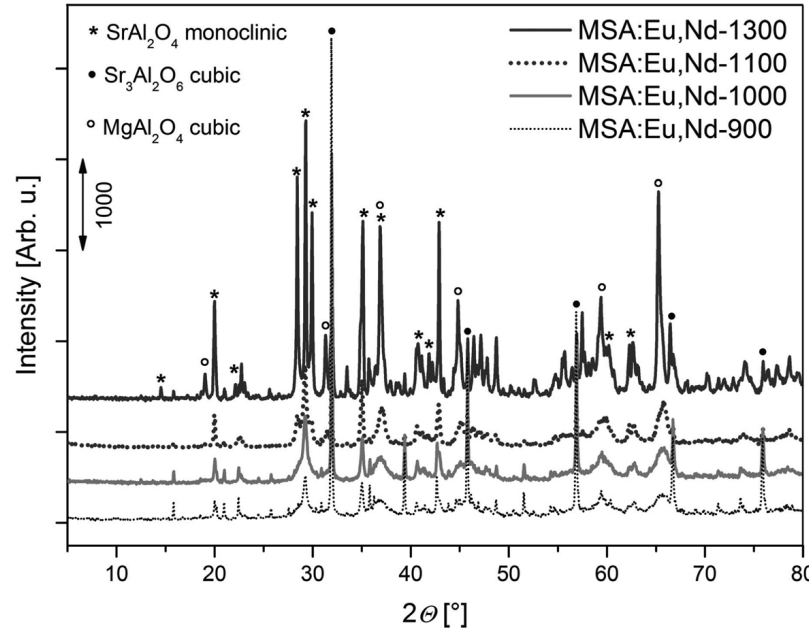

Figure 1. Crystallization and phase development with increasing temperature in a typical sample of MSA: $0.5 \mathrm{Eu}^{2+}, 0.25 \mathrm{Nd}^{3+}$, as shown by the XRD. The diffraction peaks of the individual phases are marked by symbols shown in the legend.

stable cubic $\mathrm{Sr}_{3} \mathrm{Al}_{2} \mathrm{O}_{6}$ phase (PDF 24-1187) that was fully developed at $900{ }^{\circ} \mathrm{C}$.

From Table 1 it is evident that for the CMA: $0.5 \mathrm{Eu}^{2+}, 0.25 \mathrm{Nd}^{3+}$ sample annealed at $900{ }^{\circ} \mathrm{C}$, only broad reflections of the cubic $\mathrm{MgAl}_{2} \mathrm{O}_{4}$ phase could be seen, which indicated a poorly crystalline phase. At $1000^{\circ} \mathrm{C}$ the very beginning of the monoclinic $\mathrm{CaAl}_{2} \mathrm{O}_{4}$ diffraction peaks were observed (PDF 23-1036); at $1100{ }^{\circ} \mathrm{C}$ all the diffraction peaks from both phases had narrowed; and finally the cubic $\mathrm{MgAl}_{2} \mathrm{O}_{4}$ phase (PDF 75-1799) and the monoclinic $\mathrm{CaAl}_{2} \mathrm{O}_{4}$ phase (PDF 70-134) fully crystallized at $1300{ }^{\circ} \mathrm{C}$.

Fig. 2 shows the crystalline and phase development with increased temperature of annealing for a typical sample of CSA: $0.5 \mathrm{Eu}^{2+}, 0.25 \mathrm{Nd}^{3+}$. At $900{ }^{\circ} \mathrm{C}$, three cubic phases $\mathrm{Ca}_{3} \mathrm{Al}_{2} \mathrm{O}_{6}$ (PDF 38-1429), solid solution $\mathrm{CaSr}_{2} \mathrm{Al}_{2} \mathrm{O}_{6}$ (PDF 52-249) and $\mathrm{Sr}_{3} \mathrm{Al}_{2} \mathrm{O}_{6}$ (PDF 28-1203) and two monoclinic phases $\mathrm{SrAl}_{2} \mathrm{O}_{4}$ (PDF 34-379) and $\mathrm{CaAl}_{2} \mathrm{O}_{4}$ (PDF 53-191) were present (Table 1). The cubic phases are iso- structural and their structure can be described by the general formula $\mathrm{Ca}_{x} \mathrm{Sr}_{3-\mathrm{x}} \mathrm{Al}_{2} \mathrm{O}_{6}(0 \leq x \leq 3)$. The most intense diffraction peaks of these phases, as well as both monoclinic phases, were present in the range from $28^{\circ}$ to $38^{\circ}$; therefore, this angular zone is enlarged in Fig. 2 (inset).

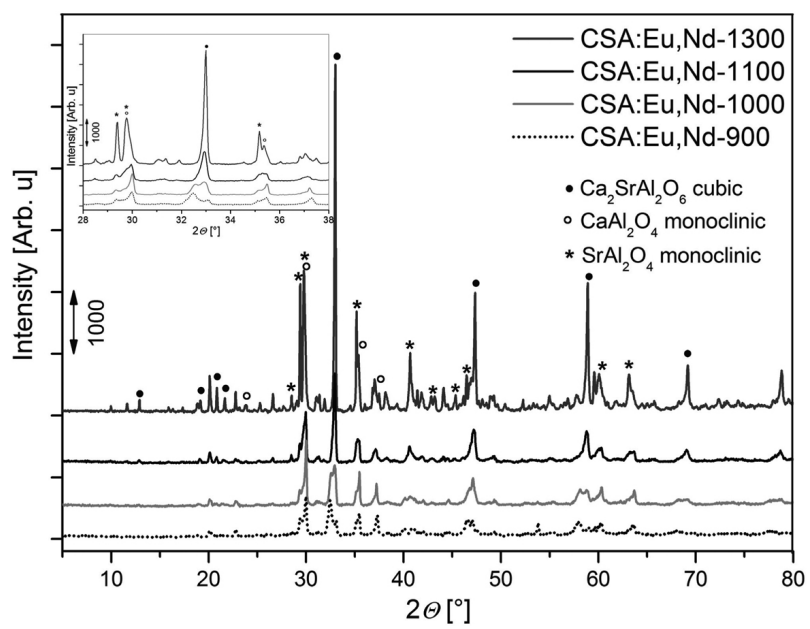

Figure 2. Crystallization and phase development with increasing temperature in a typical sample of CSA: $0.5 \mathrm{Eu}^{2+}, 0.25 \mathrm{Nd}^{3+}$, as shown by the XRD. The diffraction peaks of the individual phases are marked by symbols shown in the legend. The legend of the curves is ordered by appearance.

The peaks in the diffraction pattern at $900{ }^{\circ} \mathrm{C}$, which we have interpreted to the standard of monoclinic $\mathrm{CaAl}_{2} \mathrm{O}_{4}$ phase, were slightly shifted towards smaller angles (larger $\mathrm{d}$ values), which meant that in the present sample, at this stage, the $\mathrm{Ca}^{2+}$ ions were replaced by $\mathrm{Sr}^{2+}$ ions. There is no appropriate standard to describe this solid solution in the PDF database. ${ }^{27,28}$ At $1000{ }^{\circ} \mathrm{C}$, the composition of the mixture is very similar to that at $900{ }^{\circ} \mathrm{C}$, except that the cubic $\mathrm{Sr}_{3} \mathrm{Al}_{2} \mathrm{O}_{6}$ was no longer present. At $1100{ }^{\circ} \mathrm{C}$ the cubic $\mathrm{Ca}_{2} \mathrm{SrAl}_{2} \mathrm{O}_{6}$ phase (PDF 52-250) appeared instead of the cubic $\mathrm{CaSr}_{2} \mathrm{Al}_{2} \mathrm{O}_{6}$ phase. The former is isostructural with 
the $\mathrm{CaSr}_{2} \mathrm{Al}_{2} \mathrm{O}_{6}$ phase, only that it contains a larger proportion of $\mathrm{Ca}^{2+}$ ions. In the diffraction pattern of the sample this was observed as a shift of the diffraction peaks towards higher angles. There was also no longer any cubic $\mathrm{Ca}_{3} \mathrm{Al}_{2} \mathrm{O}_{6}$ phase present. However, both monoclinic phases were present, while the shift of the diffraction peak, which we interpreted as the monoclinic $\mathrm{CaAl}_{2} \mathrm{O}_{4}$ phase, remained the same, and the intensity of the diffraction peaks was increased and their width was narrower. In the case of 1300 ${ }^{\circ} \mathrm{C}$, the amount and crystallinity of both monoclinic phases were greatly increased, which was reflected in the diffractogram with a marked increase in the intensity and narrowing of the respective diffraction peaks $\left(\mathrm{CaAl}_{2} \mathrm{O}_{4}\right.$ : $\mathrm{PDF}$ 23-1036, $\mathrm{SrAl}_{2} \mathrm{O}_{4}$ : PDF 74-794). The same occurred with the cubic phase of the $\mathrm{Ca}_{2} \mathrm{SrAl}_{2} \mathrm{O}_{6}$ solid solution.

Beside some pure phases, we determined the existence of solid solubility at all the annealing temperatures in both the monoclinic and cubic phases. By increasing the temperature of the calcination, the proportion of calcium increased in the phase, which is a consequence of the increasing crystallinity of the calcium phases, as well as the dissolution of the strontium into the calcium network, as a result of the small difference in the size of the radii of the $\mathrm{Ca}^{2+}$ and $\mathrm{Sr}^{2+}$ ions. ${ }^{17,19}$

In all the CSA samples doped only with $\mathrm{Eu}^{2+}$ ions, at all the annealing temperatures, in contrast to monoclinic phases, solid solutions of the cubic $\mathrm{CaSr}_{2} \mathrm{Al}_{2} \mathrm{O}_{6}$ and $\mathrm{Ca}_{2} \mathrm{SrAl}_{2} \mathrm{O}_{6}$ phases were not observed. However, small amounts of pure $\mathrm{Ca}_{3} \mathrm{Al}_{2} \mathrm{O}_{6}$ phase were present. ${ }^{15}$

\section{3. Luminescence Properties}

The luminescence properties of materials depend on their crystal structures. The luminescence of the $\mathrm{Eu}^{2+}$ ion arises from the transition of $4 f^{6} 5 d^{1} \rightarrow 4 f^{7} .{ }^{29}$ The shift in the luminescence band's position for the different host lattices could be explained by a change in the crystal field effect on the $\mathrm{Eu}^{2+}$ ion. ${ }^{30}$ It is believed that the co-dopant $\mathrm{Nd}^{3+}$ caused changes in the long-lived trap levels (depths), which enhanced the lifetime of the persistent luminescence. ${ }^{6,32}$
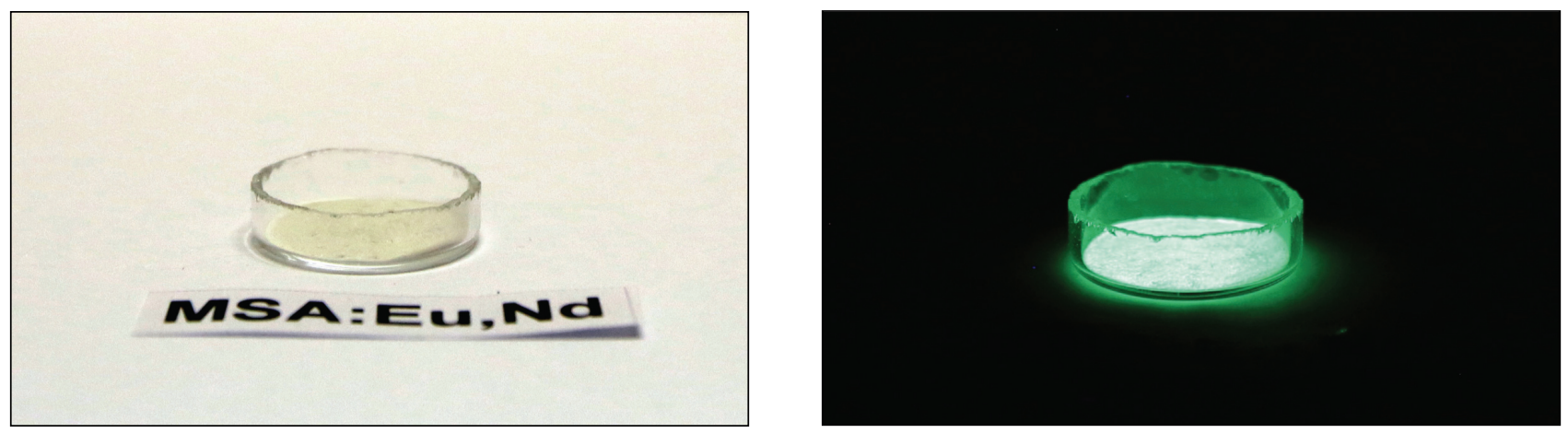

Figure 4. Photographs of the MSA: $0.5 \mathrm{Eu}^{2+}, 0.25 \mathrm{Nd}^{3+}$ sample annealed at $1300{ }^{\circ} \mathrm{C}$ in light (left) and the green luminescence in the dark (right) after the UV excitation. 
cence activity (brightness, time) compared to the monoclinic $\mathrm{SrAl}_{2} \mathrm{O}_{4}$ phase. ${ }^{31}$

Fig. 4 shows photographs of the white MSA: $0.5 \mathrm{Eu}^{2+}, 0.25 \mathrm{Nd}^{3+}$ sample (left) under daylight and the green emission in the dark after UV excitation (right).

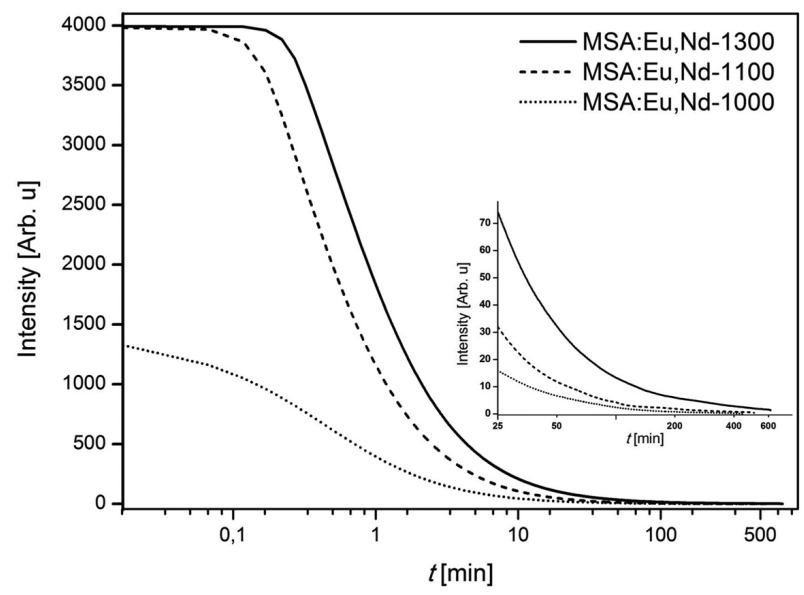

Figure 5. Persistent luminescence lifetimes of samples with the nominal formula MSA: $0.5 \mathrm{Eu}^{2+}, 0.25 \mathrm{Nd}^{3+}$, measured at room temperature. The inset graph is a magnification of the tails of the curves. The legend of the curves is ordered by appearance.

In Fig. 5 the signal curves of two samples were half a minute at the maximum intensity value, i.e., $4095\left(2^{12}-\right.$ 1). Since the conversion of the input signal into a numerical value is linear and we wanted to measure the time to sufficiently small values of persistent luminescence, we used a fully open camera shutter (f/0.95). Therefore, at the beginning of the measurements, when the signal from the samples with a large initial persistent luminescence intensity of the input light was too strong, the CCD sensor was saturated.

It turned out that the MSA: $0.5 \mathrm{Eu}^{2+}, 0.25 \mathrm{Nd}^{3+}$ sample that was calcined for 3 hours at $1300{ }^{\circ} \mathrm{C}$ exhibited green light for at least 12 hours; the duration of the measurement was limited by the measuring equipment. The middle and the last part of the curve in Fig. 5 on a log-log scale (not shown) approximate to a straight line, allowing an assessment of the intensity of the persistent luminescence in the sample to fall below the threshold of perception after an additional six hours. With manual recording of the sample after a further six hours, we confirmed that the approach to the approximation is appropriate. So, the total time of persistent luminescence for the MSA: $0.5 \mathrm{Eu}^{2+}, 0.25 \mathrm{Nd}^{3+}$ sample annealed at $1300{ }^{\circ} \mathrm{C}$ was at least 18 hours at room temperature. In this sample, the monoclinic $\mathrm{SrAl}_{2} \mathrm{O}_{4}$ phase was the dominant one, with a small percentage of the cubic $\mathrm{Sr}_{3} \mathrm{Al}_{2} \mathrm{O}_{6}$ phase, in addition to the well-crystallized cubic $\mathrm{MgAl}_{2} \mathrm{O}_{4}$ phase. The intense initial

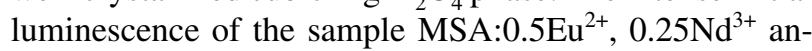
nealed at $1100{ }^{\circ} \mathrm{C}$ provided $\sim 10$ hours of luminescence, when calcined at $1000{ }^{\circ} \mathrm{C}$ for 6.7 hours, but the luminescence properties almost disappeared when the sample of MSA: $0.5 \mathrm{Eu}^{2+}, 0.25 \mathrm{Nd}^{3+}$ was calcined at $900{ }^{\circ} \mathrm{C}$. Therefore, this is not presented in Fig. 5. In its diffraction pattern, besides the well-crystallized cubic $\mathrm{Sr}_{3} \mathrm{Al}_{2} \mathrm{O}_{6}$ phase and the very small amount of hexagonal $\mathrm{SrAl}_{2} \mathrm{O}_{4}$ phase, a larger proportion of poorly crystalline cubic $\mathrm{MgAl}_{2} \mathrm{O}_{4}$ was seen, which obviously had adverse effects on the luminescence properties of the material.

The MSA: $0.5 \mathrm{Eu}^{2+}, 0.25 \mathrm{Nd}^{3+}$ sample annealed at $1300{ }^{\circ} \mathrm{C}$ had a three-times longer persistent luminescence than the sample that was prepared at the same temperature, but with the same amount of europium only. ${ }^{15}$ In the sample of MSA: $\mathrm{Eu}^{2+}$ annealed at $1100{ }^{\circ} \mathrm{C}$, which was without luminescence activity, ${ }^{15}$ added $\mathrm{Nd}^{3+}$ ions resulted in 10 hours of persistent luminescence. A thirteen-times longer persistent luminescence was achieved in the sample co-doped with $\mathrm{Nd}^{3+}$ ions calcined at $1000{ }^{\circ} \mathrm{C}$, but it was almost 3.5 hours shorter due to the lack of a pure $\mathrm{SrAl}_{2} \mathrm{O}_{4}$ host lattice at $900{ }^{\circ} \mathrm{C}$ in addition to the above-mentioned reasons.

In the group of aluminates containing calcium (CMA and CSA) doped with $\mathrm{Eu}^{2+}$ and $\mathrm{Nd}^{3+}$ ions, all the phosphors emitted light in the blue region $\sim 440 \mathrm{~nm}$ after the excitation with UV light with a wavelength of $350 \mathrm{~nm}$ (Fig. 6), which again confirmed that the host lattice for the luminescent centre $\mathrm{Eu}^{2+}$ is the monoclinic $\mathrm{CaAl}_{2} \mathrm{O}_{4}$ phase, as already reported. ${ }^{15}$ The CMA: $0.5 \mathrm{Eu}^{2+}, 0.25 \mathrm{Nd}^{3+}$ sample calcined at $900{ }^{\circ} \mathrm{C}$ did not show any luminescence activity, since the crystallized calcium monoclinic $\mathrm{CaAl}_{2} \mathrm{O}_{4}$ phase did not appear (Table 1).

For the sample CSA:0.5 $\mathrm{Eu}^{2+}, 0.25 \mathrm{Nd}^{3+}$, which was calcined at $1300{ }^{\circ} \mathrm{C}$, changes in the shape of the band were observed, i.e., an extended shoulder in the green area, which was the result of the luminescence activity of the $\mathrm{Eu}^{2+}$ ion in the crystal lattice of the $\mathrm{SrAl}_{2} \mathrm{O}_{4}$ phase.

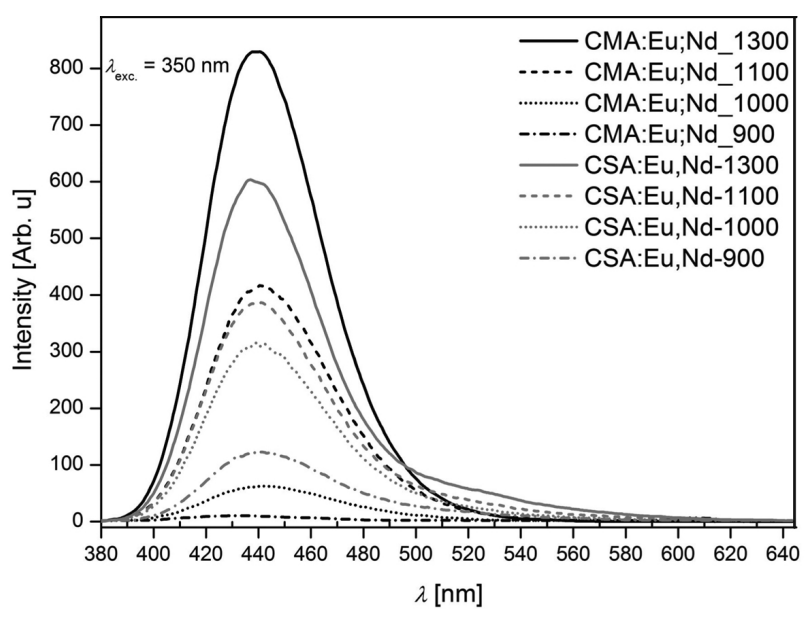

Figure 6. UV-excited $\left(\lambda_{\text {exc. }}=350 \mathrm{~nm}\right)$ emission spectra of the CMA:0.5 $\mathrm{Eu}^{2+}, 0.25 \mathrm{Nd}^{3+}$ and CSA:0.5 $\mathrm{Eu}^{2+}, 0.25 \mathrm{Nd}^{3+}$ samples annealed at different temperatures in a reducing atmosphere, measured at room temperature. 
However, the luminescence in this region was much weaker than in the case of the CSA: $\mathrm{Eu}^{2+} .{ }^{15}$ The colour of the observed light in the dark for the CSA:0.5 $\mathrm{Eu}^{2+}$, $0.25 \mathrm{Nd}^{3+}$ sample was almost whitish-indigo to violet (Fig. 7). The degree of crystallinity of the host monoclinic $\mathrm{CaAl}_{2} \mathrm{O}_{4}$ phase influences the intensity of the persistent luminescence in all the samples, with a maximum at $1300{ }^{\circ} \mathrm{C}$.

The highest intensity of emitted light was from the fully crystallized (monoclinic $\mathrm{CaAl}_{2} \mathrm{O}_{4}$, cubic $\mathrm{MgAl}_{2} \mathrm{O}_{4}$ ) sample CMA: $0.5 \mathrm{Eu}^{2+}, 0.25 \mathrm{Nd}^{3+}$ annealed at $1300{ }^{\circ} \mathrm{C}$. The first minute of the measurement resulted in saturation of the signal (Fig. 8), and afterwards the luminescence lasted for more than 1000 minutes $(16.7 \mathrm{~h})$. The approximation with a straight line on a log-log scale (not shown) predicted a persistent luminescence lasting approximately 2000 minutes ( 33 hours), which was confirmed by visual observation with the camera. At $1100{ }^{\circ} \mathrm{C}$, both crystalline phases were present with smaller crystallites, yielding 13.3 hours of blue persistent luminescence. The shortest persi-

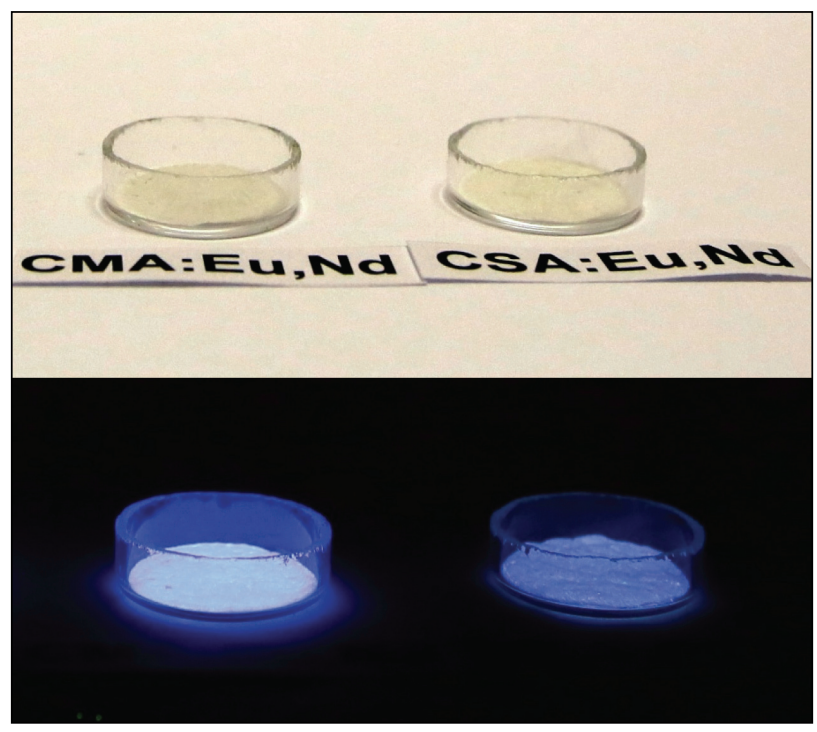

Figure 7. Photographs of the CMA:0.5Eu ${ }^{2+}, 0.25 \mathrm{Nd}^{3+}$ and CSA: $0.5 \mathrm{Eu}^{2+}, 0.25 \mathrm{Nd}^{3+}$ samples annealed at $1300{ }^{\circ} \mathrm{C}$ in light (above) and in the dark (below) after UV excitation.

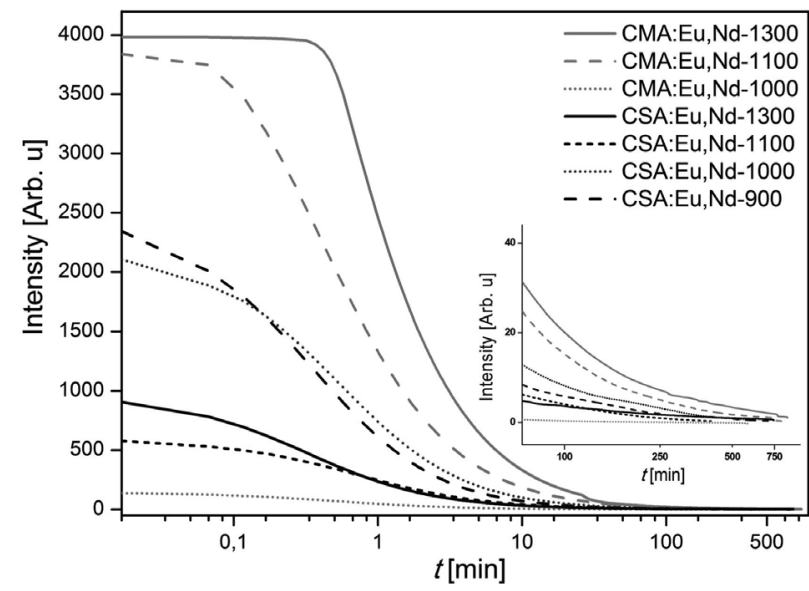

Figure 8. Persistent luminescence lifetimes of samples with the nominal formulae CMA: $0.5 \mathrm{Eu}^{2+}, 0.25 \mathrm{Nd}^{3+}$ and CSA: $0.5 \mathrm{Eu}^{2+}, 0.25 \mathrm{Nd}^{3+}$ measured at room temperature. The inset graph is a magnification of the tails of the curves. The legend of the curves is ordered by appearance.

stent luminescence of 2 hours with a smaller intensity was observed for the CMA: $0.5 \mathrm{Eu}^{2+}, 0.25 \mathrm{Nd}^{3+}$ sample annealed at $1000{ }^{\circ} \mathrm{C}$, as expected, since the sample contained only trace amounts of the crystalline monoclinic $\mathrm{CaAl}_{2} \mathrm{O}_{4}$ phase as well as a larger proportion of the poorly crystalline cubic $\mathrm{MgAl}_{2} \mathrm{O}_{4}$ phase.

A comparison with the CMA samples that were only $\mathrm{Eu}^{2+}$-doped ${ }^{15}$ showed the maximum difference for the CMA sample annealed at $1300^{\circ} \mathrm{C}$. A few minutes of blue signal with only the $\mathrm{Eu}^{2+}$ ions was extended to at least 24 hours when $\mathrm{Nd}^{3+}$ ions were present, and in the sample annealed at $1100{ }^{\circ} \mathrm{C}$ the total time of persistent luminescence was almost five-times longer compared to non-co-doped CMA: $0.5 \mathrm{Eu}^{2+}$. At lower annealing temperatures both materials showed low or no luminescent activity due to the poor crystallinity of the materials.

The solid solubility of strontium in the monoclinic $\mathrm{CaAl}_{2} \mathrm{O}_{4}$ phase and also in the cubic phases of $\mathrm{Ca}_{x} \mathrm{Sr}_{3-}$ ${ }_{x} \mathrm{Al}_{2} \mathrm{O}_{6}(0 \leq \mathrm{x} \leq 3)$ in the CSA: $0.5 \mathrm{Eu}^{2+}, 0.25 \mathrm{Nd}^{3+}$ samples at 1100 and $1300{ }^{\circ} \mathrm{C}$ caused a decrease of the luminescence activity in aluminates compared to the CMA: $0.5 \mathrm{Eu}^{2+}, 0.25 \mathrm{Nd}^{3+}$ samples at 1100 and $1300{ }^{\circ} \mathrm{C}$. In those

Table 2. Comparison of the luminescence activity (in hours) between only $\mathrm{Eu}^{2+}$ doped samples ${ }^{15}$ and samples with $\mathrm{Eu}^{2+}$ and $\mathrm{Nd}^{3+}$ co-doped ions.

\begin{tabular}{|c|c|c|c|c|}
\hline \multirow[b]{2}{*}{ Sample } & \multicolumn{4}{|c|}{ Temperature } \\
\hline & $900{ }^{\circ} \mathrm{C}$ & $1000{ }^{\circ} \mathrm{C}$ & $1100{ }^{\circ} \mathrm{C}$ & $1300{ }^{\circ} \mathrm{C}$ \\
\hline$\overline{\text { MSA:0.5Eu }}{ }^{2+}$ & $3.9 \mathrm{~h}$ & $0.6 \mathrm{~h}$ & low & $6.1 \mathrm{~h}$ \\
\hline MSA:0.5Eu ${ }^{2+} 0.25 \mathrm{Nd}^{3+}$ & $0.4 \mathrm{~h}$ & $6.7 \mathrm{~h}$ & $10 \mathrm{~h}$ & $18 \mathrm{~h}$ \\
\hline$\overline{\text { CMA:0.5Eu }}{ }^{2+}$ & / & l & $2.5 \mathrm{~h}$ & $0.2 \mathrm{~h}$ \\
\hline CMA:0.5Eu ${ }^{2+} 0.25 \mathrm{Nd}^{3+}$ & / & $2 \mathrm{~h}$ & $13.3 \mathrm{~h}$ & $33 \mathrm{~h}$ \\
\hline$\overline{\mathrm{CSA}: 0.5 \mathrm{Eu}^{2+}}$ & $1.9 \mathrm{~h}$ & $2.4 \mathrm{~h}$ & low & $7.5 \mathrm{~h}$ \\
\hline $\mathrm{CSA}: 0.5 \mathrm{Eu}^{2+} 0.25 \mathrm{Nd}^{3+}$ & $12 \mathrm{~h}$ & $12 \mathrm{~h}$ & $8.3 \mathrm{~h}$ & $13 \mathrm{~h}$ \\
\hline
\end{tabular}


samples, the persistent luminescence intensity was considerably lower (Fig. 8). The persistent luminescence duration was 8.3 hours for the sample of CSA:0.5 $\mathrm{Eu}^{2+}$, $0.25 \mathrm{Nd}^{3+}$ calcined at $1100{ }^{\circ} \mathrm{C}$, and 13 hours for the sample of CSA: $0.5 \mathrm{Eu}^{2+}, 0.25 \mathrm{Nd}^{3+}$ calcined at $1300{ }^{\circ} \mathrm{C}$, which was 5.5 hours longer than for the CSA: $0.5 \mathrm{Eu}^{2+}$ annealed at the same temperature. ${ }^{15}$ In the CSA: $0.5 \mathrm{Eu}^{2+}, 0.25 \mathrm{Nd}^{3+}$ samples calcined at $900{ }^{\circ} \mathrm{C}$ and $1000{ }^{\circ} \mathrm{C}$, the time of persistent luminescence was prolonged from $\sim 2$ hours to 12 hours, compared to the CSA:0.5 $\mathrm{Eu}^{2+}$ annealed at the same temperatures.

Finally, the comparison of the luminescence activity between samples doped with $\mathrm{Eu}^{2+}$ ions only ${ }^{15}$ and samples with $\mathrm{Eu}^{2+}$ and $\mathrm{Nd}^{3+}$ co-doped ions is presented in Table 2.

\section{Conclusions}

A modified aqueous sol-gel method employing nitric acid as a peptizing agent was used to obtain xerogels as precursors of alkaline earth aluminates doped with $\mathrm{Eu}^{2+}$ ions and co-doped with $\mathrm{Nd}^{3+}$ ions, thus enabling the preparation of the materials in a reducing atmosphere without a carbon residual. Efficient luminescent properties could be achieved at annealing temperatures lower than those required in conventional solid state reactions.

Structural studies showed the presence of various phases obtained at different annealing temperatures. All the crystalline aluminates were mixtures of at least two phases. The monoclinic phase of $\mathrm{CaAl}_{2} \mathrm{O}_{4}$, the hexagonal and/or monoclinic phases of $\mathrm{SrAl}_{2} \mathrm{O}_{4}$, the cubic phases of $\mathrm{Ca}_{\mathrm{x}} \mathrm{Sr}_{3-\mathrm{x}} \mathrm{Al}_{2} \mathrm{O}_{6}(0 \leq \mathrm{x} \leq 3)$ and the cubic phase of $\mathrm{MgAl}_{2} \mathrm{O}_{4}$ were all identified in the samples.

The solid solubility of strontium in the monoclinic phase of $\mathrm{CaAl}_{2} \mathrm{O}_{4}$ in the CSA: $0.5 \mathrm{Eu}^{2+}, 0.25 \mathrm{Nd}^{3+}$ samples at all the annealing temperatures was confirmed. Solid solubility was also observed in the cubic phase of $\mathrm{Ca}_{x} \mathrm{Sr}_{3-}$ ${ }_{x} \mathrm{Al}_{2} \mathrm{O}_{6}(0 \leq x \leq 3)$, in addition to some pure phases (hexagonal and/or monoclinic) of $\mathrm{SrAl}_{2} \mathrm{O}_{4}$. As expected, solid solubility was not observed in the CMA: $0.5 \mathrm{Eu}^{2+}, 0.25 \mathrm{Nd}^{3+}$ and MSA: $0.5 \mathrm{Eu}^{2+}, 0.25 \mathrm{Nd}^{3+}$ samples.

The band positions of the UV-excited emission spectra depend on the crystal structure of the host lattice for $\mathrm{Eu}^{2+}$ ions, while $\mathrm{Nd}^{3+}$ ions prolong the luminescence activity. UV-excited luminescence was observed in the green region $\left(\lambda_{\max }=512 \mathrm{~nm}\right)$ in the MSA: $0.5 \mathrm{Eu}^{2+}$, $0.25 \mathrm{Nd}^{3+}$ sample, corresponding to the crystal structures of the $\mathrm{SrAl}_{2} \mathrm{O}_{4}$ phases.

UV-excited luminescence in the blue region $\left(\lambda_{\max }=\right.$ $440 \mathrm{~nm}$ ) was observed in the CMA: $0.5 \mathrm{Eu}^{2+}, 0.25 \mathrm{Nd}^{3+}$ and CSA: $0.5 \mathrm{Eu}^{2+}, 0.25 \mathrm{Nd}^{3+}$ samples containing the monoclinic $\mathrm{CaAl}_{2} \mathrm{O}_{4}$ phase, indicating that this phase defines the luminescence properties of the material. However, in the CSA: $0.5 \mathrm{Eu}^{2+}, 0.25 \mathrm{Nd}^{3+}$ the luminescence turned out to be a whitish-indigo to violet colour, corresponding to the presence of some pure phases of $\mathrm{SrAl}_{2} \mathrm{O}_{4}$, which caused additional UV-excited luminescence in the green region $\left(\lambda_{\max }=512 \mathrm{~nm}\right)$. The longest persistent luminescence activity was shown by materials annealed at $1300{ }^{\circ} \mathrm{C}$. The MSA: $0.5 \mathrm{Eu}^{2+}, 0.25 \mathrm{Nd}^{3+}$ and CSA: $0.5 \mathrm{Eu}^{2+}, 0.25 \mathrm{Nd}^{3+}$ samples exhibited luminescence in darkness for 18 and 13 hours, respectively, while the CMA: $0.5 \mathrm{Eu}^{2+}, 0.25 \mathrm{Nd}^{3+}$ sample showed luminescence activity for 33 hours.

\section{Acknowledgements}

Financial support from the Slovenian Research Agency (ARRS), Ljubljana, (P-0134) is gratefully acknowledged.

\section{References}

1. Z. Tang, F. Zhang, Z. Zhang, C. Huang, Y. Lin, J. Eur. Ceram. Soc. 2000, 20, 2129-2132.

http://dx.doi.org/10.1016/S0955-2219(00)00092-3

2. T. Aitasalo, P. Deren, J. Hölsä, H. Jungner, J.-C. Krupa, M. Lastusaari, J. Legendziewicz, J. Niitykoski, W. Strek, J. Solid State Chem. 2003, 171, 114-122. http://dx.doi.org/10.1016/S0022-4596(02)00194-9

3. P. Sharma, D. Haranath, H. Chander, S. Singh, Appl. Surf. Sci. 2008, 254, 4052-4055.

http://dx.doi.org/10.1016/j.apsusc.2007.12.040

4. H. Ryu, K. S. Bartwal, Res. Lett. Mater. Sci. 2007, 2007, $1-4$.

5. M. Ayvacýklý, A. Ege, S.Yerci, N. Can, J. Lumin. 2011, 131, 2432-2439. http://dx.doi.org/10.1016/j.jlumin.2011.05.051

6. K.Van den Eeckhout, P. F. Smet, D. Poelman, Materials 2010, 3, 2536-2566. http://dx.doi.org/10.3390/ma3042536

7. J. Hölsä, H. Jungner, M. Lastusaari, J. Niittykoski, J. Alloys Compd. 2001, 323-324, 326-330. http://dx.doi.org/10.1016/S0925-8388(01)01084-2

8. H. Ryu, K. S. Bartwal, Open Appl. Phys. J. 2009, 2, 1-4.

9. A. S. Maia, R. Stefani, C. A. Kodaira, M. C. F. C. Felinto, E. E. S. Teotonio, H. F. Brito, Opt. Mater. 2008, 31, 440-444. http://dx.doi.org/10.1016/j.optmat.2008.06.017

10. B. Yan, J. Wu, Mater. Lett. 2007, 61, 4851-4853. http://dx.doi.org/10.1016/j.matlet.2007.03.058

11. S. Janakova, L. Salavcova, G. Renaudin, Y. Filinchuk, D. Boyer, P. Boutinaud, J. Phys. Chem. Solids 2007, 68, 11471151. http://dx.doi.org/10.1016/j.jpcs.2006.12.034

12. T. Aitasalo, J. Hölsä, H. Jungner, M. Lastusaari, J. Niittykoski, J. Saarinen, Opt. Mater. 2005, 27, 1537-1540. http://dx.doi.org/10.1016/j.optmat.2005.03.001

13. T. Aitasalo, J. Hölsä, H. Jungner, M. Lastusaari, J. Niittykoski, Mater. Sci. 2002, 20, 15-20.

14. P. Escribano, M. Marchal, M. L. Sanjuán, P. Alonso-Gutiérrez, B. Julián, E. Cordoncillo, J. Solid State Chem. 2005, 178, 1978-1987. http://dx.doi.org/10.1016/j.jssc.2005.04.001

15. N. Čelan Korošin, A. Meden, N. Bukovec, Acta Chim. Slov. 
2012, 59, 912-919.

16. N. Čelan Korošin, V. Francetič, N. Bukovec, J. Therm. Anal. Calorim. 2013, 111, 1291-1296. http://dx.doi.org/10.1007/s10973-012-2451-y

17. T. Aitasalo, J. Hölsä, H. Jungner, J.-C. Krupa, M. Lahtinen, M. Lastusaari, J. Legendziewicz, J. Niitykoski, J. Valkonen, Radiat. Eff. Defects S. 2003, 158, 309-313. http://dx.doi.org/10.1080/1042015021000052836

18. L.-T. Chen, C.-S. Hwang, I-L. Sun, I.-G. Chen, J. Lumin. 2006, 118, 12-20. http://dx.doi.org/10.1016/j.jlumin.2005.06.003

19. A. K. Prodjosantoso, B. J. Kennedy, Mater. Res. Bull. 2003, 38, 79-87. http://dx.doi.org/10.1016/S0025-5408(02)01009-7

20. H. Lange, Luminescent Europium Activated Strontium Aluminate, US patent number 3,294,699, date of patent Dec 27, 1966. http://dx.doi.org/10.1021/jp057185m

21. T. Aitasalo, J. Hölsä, H. Jungner, M. Lastusaari, J. Niittykoski, J. Phys. Chem. B 2006, 110, 4589-4598.

22. T. Matsuzawa, Y. Aoki, N. Takeuchi, Y. Murayama, J. Electrochem. Soc. 1996, 143, 2670-2673. http://dx.doi.org/10.1149/1.1837067

23. H. Takasaki, S. Tanabe, T. Hanada, J. Ceram. Soc. Jpn 1996, 104, 322-326. http://dx.doi.org/10.2109/jcersj.104.322
24. T. Aitasalo, J. Hölsä, H. Jungner, M. Lastusaari, J. Niittykoski, M. Parkkinen, R. Valtonen, Opt. Mater. 2004, 26, 113- 116. http://dx.doi.org/10.1016/j.optmat.2003.11.007

25. Z. Qiu, Y. Zhou, M. Lu, A. Zhang, Q. Ma, Acta Mater. 2007, 55, 2615-2620. http://dx.doi.org/10.1016/j.actamat.2006.12.018

26. C. Zhao, D. Chen, Mater. Lett. 2007, 61, 3673-3675. http://dx.doi.org/10.1016/j.matlet.2006.12.015

27. Crystallographica Search Match Version 3.1.0, Oxford cryosystems Ltd, Oxford, UK 2008.

28. International Centre for Diffraction Data (2011), PDF-2, Newtown Square, PA, USA 2011.

29. F. Clabau, X. Rocquefelte, S. Jobic, P. Deniard, M.-H. Whangbo, A. Garcia, T. Le Mercie, Chem. Mater. 2005, 15, 3904-3912. http://dx.doi.org/10.1021/cm050763r

30. B. Blasse, B. C. Grabmaier: Luminescent materials, Springer Verlag; Berlin, 1994. http://dx.doi.org/10.1007/978-3-642-79017-1

31. P. Huang, C. Cui, S. Wang, Opt. Mater. 2009, 32, 184-189. http://dx.doi.org/10.1016/j.optmat.2009.07.008

32. L. C. V. Rodrigues, J. Hölsä, J. M. Carvalho, C. C. S. Pedroso, M. Lastusaari, M. C. F. C. Felinto, S. Watanabe, H. F. Brito, Physica B 2014; 439, 67-71. http://dx.doi.org/10.1016/j.physb.2013.11.007

\section{Povzetek}

Zemeljskoalkalijske aluminate $\mathrm{z}$ nominalno sestavo $\mathrm{Mg}_{0.5} \mathrm{Sr}_{0.5} \mathrm{Al}_{2} \mathrm{O}_{4}$ (MSA), $\mathrm{Ca}_{0.5} \mathrm{Mg}_{0.5} \mathrm{Al}_{2} \mathrm{O}_{4}(\mathrm{CMA})$ in $\mathrm{Ca}_{0.5} \mathrm{Sr}_{0.5} \mathrm{Al}_{2} \mathrm{O}_{4}$ (CSA) dopirane z $0.5 \mathrm{~mol} \% \mathrm{Eu}^{2+}$ in $0.25 \mathrm{~mol} \% \mathrm{Nd}^{3+}$ ionov, smo pripravili z modificirano vodno sol-gel metodo in žganjem v reduktivni atmosferi pri $900,1000,1100$ in $1300^{\circ} \mathrm{C}$. Strukture vzorcev smo določili z XRD. Trdno topnost smo potrdili le v CSA vzorcih. V CMA vzorcih, ki vsebujejo monoklinsko fazo $\mathrm{CaAl}_{2} \mathrm{O}_{4}$, smo opazili UV-vzbujeno luminiscenco v območju modre svetlobe $(\lambda=440 \mathrm{~nm})$, v vzorcih MSA, ki vsebujejo heksagonalno in monoklinsko fazo Sr$\mathrm{Al}_{2} \mathrm{O}_{4}$, pa v območju zelene svetlobe $(\lambda=512 \mathrm{~nm})$. V CSA vzorcih je poleg luminescence $\mathrm{v}$ območju modre svetlobe prisoten še širši trak, ki sega $\mathrm{v}$ območje zelene svetlobe, kar potrjuje prisotnost čistih stroncijevih faz. Dodatni Nd ${ }^{3+}$ ioni ne vplivajo na valovno dolžino emitirane svetlobe, podaljšajo pa čas obstojne luminescence pri sobni temperaturi glede na aluminate, ki so dopirani samo $\mathrm{z} \mathrm{Eu}^{2+}$ ioni. 